\title{
Pharmacokinetics and tissue residue of toltrazuril in broiler chickens
}

\author{
Ahmed M. Soliman \\ Department of Pharmacology, Faculty of Veterinary Medicine, Cairo University, Giza \\ E-mail: galalpharma@hotmail.com
}

Copyright $\odot 2015$ Ahmed M. Soliman. This is an open access article distributed under the Creative Commons Attribution License, which permits unrestricted use, distribution, and reproduction in any medium, provided the original work is properly cited.

\begin{abstract}
The pharmacokinetics and tissue residue of toltrazuril (Baycox ${ }^{\circledR}$, Bayer Animal Health) were investigated in broiler chickens after repeated oral administrations of $7 \mathrm{mg} / \mathrm{kg}$ b.wt once daily for two consecutive days. Chickens were subjected to clinical diagnosis to ensure that each one is free from any Eimeria was received a standard broiler feed free from any medications. The results revealed that following repeated oral administration; toltrazuril peaked in blood with $\left[\mathrm{C}_{\max }\right]$ of 6.56 and $6.70 \mu \mathrm{g} / \mathrm{ml}$ at $\left[\mathrm{T}_{\max }\right]$ of 2.56 and 2.52 hours and the elimination half-life [ $\mathrm{t}_{1 / 2 \beta}$ ] of 14.92 and 16.19 hours and the mean residence times (MRT) were 21.33 and 23.14 hours after first and second doses, respectively. The tissue level concentrations were highest in the kidney and decreased in the following order: liver $>$ lung $>$ heart $>$ muscle > skin and fat. No toltrazuril residues were detected in tissues and plasma after 8 days.
\end{abstract}

Keywords: Broiler; Disposition; Pharmacokinestics; Tissue Residue; Toltrazuril.

\section{Introduction}

Intestinal coccidiosis, caused by various species of Eimeria, is an economically important infectious disease of poultry and reared livestock throughout the world caused by Eimeria tenella, the most pathogenic strain of coccidium is usually located in cecum and leading to cecal coccidiosis [1], [2]. There have been applied several drugs to minimize the possible negative effects of infection [3].

During commercial broiler chicken production, chickens are continually exposed to coccidial oocysts found in litter [9]. Moreover, broiler chickens will have multiple stages of coccidial development simultaneously. After clinical signs of coccidiosis appear in a broiler chickens facility, it may be too late to therapeutically control the infection in all birds unless the therapeutic anti-coccidial is against multiple stages of development [1].

The aim of the present study is to estimate the concentrations of toltrazuril and investigate the pharmacokinetics and tissue residue of toltrazuril following a repeated oral administration (for 2 consecutive days) in broiler chickens.

\section{Materials and methods}

\subsection{Birds}

Forty five white leghorn broiler chickens (one month old) were used in this study. Chickens were subjected to clinical diagnosis to ensure that each one is free from any Eimeria. They were kept individually in cages, within a ventilated, heated room $\left(20^{\circ} \mathrm{C}\right)$, and 14 hours of day light. They received a standard broiler feed free from any medications and water ad. Libitum. The protocols for the bird studies were approved by the Institutional Animal Care and Use Committee (IACUC) of Cairo University. 


\subsection{Drug}

Baycox $^{\circledR}$ (Bayer Animal Health): It is available as $500 \mathrm{ml}$ or $100 \mathrm{ml}$ oral solution in high density polyethylene bottles. Each one ml contains $25 \mathrm{mg}$ toltrazuril base (2.5\%).

\subsection{Experimental design}

Chicks were received and raised till one month old with normal vaccination and medication programs. All Chickens were received toltrazuril $7 \mathrm{mg} / \mathrm{kg}$ b.wt orally (intra-crop administered) with Baycox ${ }^{\circledR}$ for 2 consecutive days.

\subsection{Pharmacokinetics and tissue residue studies}

Blood samples (one $\mathrm{ml}$ ) were collected from the right-wing vein from 10 chickens before medication and at $0.25,0.5,1$, 2, 4, 6, 8, 12 and 24 hour after the first and second doses. Blood samples were allowed to clot at room temperature and then centrifuged at 3000 r.p.m. $/ 10$ minutes. The resulting serum was stored at $-20^{\circ} \mathrm{C}$ until analysis. 24 hours following the second dose, three chickens were slaughtered on daily bases for 15 days. Tissue samples (lung, heart, liver, kidney, breast muscle, thigh muscle, skin and fat) were taken and stored at $-20{ }^{\circ} \mathrm{C}$ until analysis.

\subsection{Toltrazuril analysis}

Serum and tissue concentrations of toltrazuril were determined using a high performance liquid chromatographic (HPLC) method. The HPLC method and extraction procedures were used from previously published methods [10, 11]. Frozen serum samples were thawed at room temperature and $100 \mu$ of the sample was mixed with $400 \mu 1$ of ethyl acetate and vortex mixed for $5 \mathrm{~min}$ and then centrifuged at 1,000 x g for $10 \mathrm{~min}$ at room temperature. The organic layer was transferred to a clean tube and evaporated under a steam of nitrogen at $40^{\circ} \mathrm{C}$. The residue was re-constituted with $100 \mu \mathrm{l}$ of acetonitrile and vortex mixed for $5 \mathrm{~min}$. This was filtered through a $0.22 \mu \mathrm{m}$ syringe filter to remove the insoluble proteins, and the clear filtrate was transferred into an auto sampler vial and $50 \mu \mathrm{l}$ was injected into the HPLC system.

For the tissue samples, three $\mathrm{ml}$ of acetonitrile were added to one gram of the obtained tissue sample and homogenized in a porcelain mortar by the aid of sterile sand. The homogenate was left in the refrigerator overnight then centrifuged. The supernatant was collected and subjected to the same manner in serum samples.

The HPLC system consisted of a Beckman System Gold® 126 solvent module, a Beckman model 508 auto sampler, a Beckman model, 168 detector (Beckman Coulter) and a reversed phase C18 (3 $\mu \mathrm{m}, 125 \mathrm{X} 4.6 \mathrm{~mm})$ Column (Phenomenex, Germany) with an isocratic mobile phase which consists of Water HPLC and acetonitrile HPLC (20:80 $\mathrm{v} / \mathrm{v})$. The mobile phase was eluted at a flow rate of $1 \mathrm{~mL} / \mathrm{min}$ and detected at a UV wave length of $254 \mathrm{~nm}$.

\subsection{Toltrazuril calibration curve}

A standard calibration curve was prepared by adding one $\mathrm{ml}$ of toltrazuril base $(25 \mathrm{mg} / \mathrm{ml})$ to nine $\mathrm{ml}$ chicken serum or acetonitrile. This was further diluted to produce standards of $0.5,1,2.5,5,10,25,50$ and $100 \mu \mathrm{g}$ toltrazuril $/ \mathrm{ml}$. These standards were extracted and analyzed in the same manner as unknown samples. The HPLC method for toltrazuril determination in chicken serum was validated by assessing linearity, precision, accuracy and recovery. Two sets of quality control samples $(5,20$ and $80 \mu \mathrm{g}$ toltrazuril $/ \mathrm{ml})$ were prepared and analyzed at the beginning and at the end of each assay to determine the intra- and inter-assay coefficients of variation $(\mathrm{CV})$. The calibration curves were linear over the range of $0.5-100 \mu \mathrm{g} / \mathrm{ml} \mathrm{g} / \mathrm{ml}$, and the correlation coefficients $\left(\mathrm{r}^{2}\right)$ were $>0.999$. Analytical recovery of toltrazuril, calculated by comparing the peak height ratios for serum samples and aqueous samples, ranging $82-87 \%$. The interassay CV was 3, 3 and 5\%, while the intra-assay CV were 4, 5 and $8 \%$, respectively at toltrazuril concentrations of 5, 20 and $80 \mu \mathrm{g} / \mathrm{ml}$.

\subsection{Pharmacokinetic and statistical analysis}

The pharmacokinetic parameters of toltrazuril were calculated by using a non-compartmental software program (WinNonlin ${ }^{\circledR}$ software, version 5.2, Pharsight Corporation, NC, USA). The area under serum concentration-time curve (AUC) was calculated using the trapezoidal rule with extrapolation to infinity. The maximum concentration $\left(\mathrm{C}_{\max }\right)$ and the corresponding peak time $\left(\mathrm{t}_{\max }\right)$ were determined by the inspection of the individual drug serum concentration-time profiles. The slope of the terminal phase of the time-concentration curve was determined by linear regression and converted to an elimination half-life $\left(\mathrm{t}_{1 / 2 \beta}\right)$ by multiplying the reciprocal by 0.693 .

Data were expressed as $\mathrm{X} \pm \mathrm{SE}$. and were statistically analyzed using analysis of variance. Mean comparisons were performed using Tukey's test. The differences were considered significant when $\mathrm{p}<0.05$. These calculations were performed using Prism 5.0 (GraphPad). 


\section{Results}

The mean serum concentration-time curve of toltrazuril following repeated oral administration at a dose of $7 \mathrm{mg} / \mathrm{kg}$ b.wt is plotted and presented graphically in Figure 1. The pharmacokinetic parameters of toltrazuril are shown in Table 1. Following a repeated oral administration for two consecutive days, the mean $\mathrm{AUC}_{0-\infty}$ was $131.65 \pm 4.45$ and $144.23 \pm 6.34$ $\mu \mathrm{g} / \mathrm{ml} / \mathrm{h}$, and the elimination half-life $\left(\mathrm{t}_{1 / 2 \beta}\right)$ was $14.92 \pm 1.28$ and $16.19 \pm 1.60$ hours and the mean residence times $\left(\mathrm{MRT}_{0-}\right.$ $\left.{ }_{\infty}\right)$ were $21.33 \pm 1.90$ and $23.14 \pm 1.66$ hours following administration of the first and second doses, respectively. The maximum serum concentration $\left(\mathrm{C}_{\max }\right)$ was $6.56 \pm 1.26$ and $6.70 \pm 0.60 \mu \mathrm{g} / \mathrm{ml}$ reached at $\mathrm{T}_{\max }$ of $2.56 \pm 0.16$ and $2.59 \pm 0.35$ hours following administration of the first and second doses, respectively. Tissue residue profiles of toltrazuril are incorporated in Table 2. The tissue level concentrations were highest in the kidney and decreased in the following order: liver $>$ lung $>$ heart $>$ muscle $>$ skin and fat. No toltrazuril residues were detected in tissues and plasma after 8 days following repeated oral administration.

Figure Legend:

Fig 1 the serum concentration-time profile of toltrazuril $(7 \mathrm{mg} / \mathrm{kg}$ bw) after repeated oral administration for 2 consecutive days in broiler chickens. Maximum serum concentration $\left(C_{\max }\right)$ was 6.56 and $6.70 \mu \mathrm{g} / \mathrm{ml} \mathrm{reached} \mathrm{at} \mathrm{T}_{\max }$ of 2.56 and 2.59 hours following administration of the first and second doses, respectively.

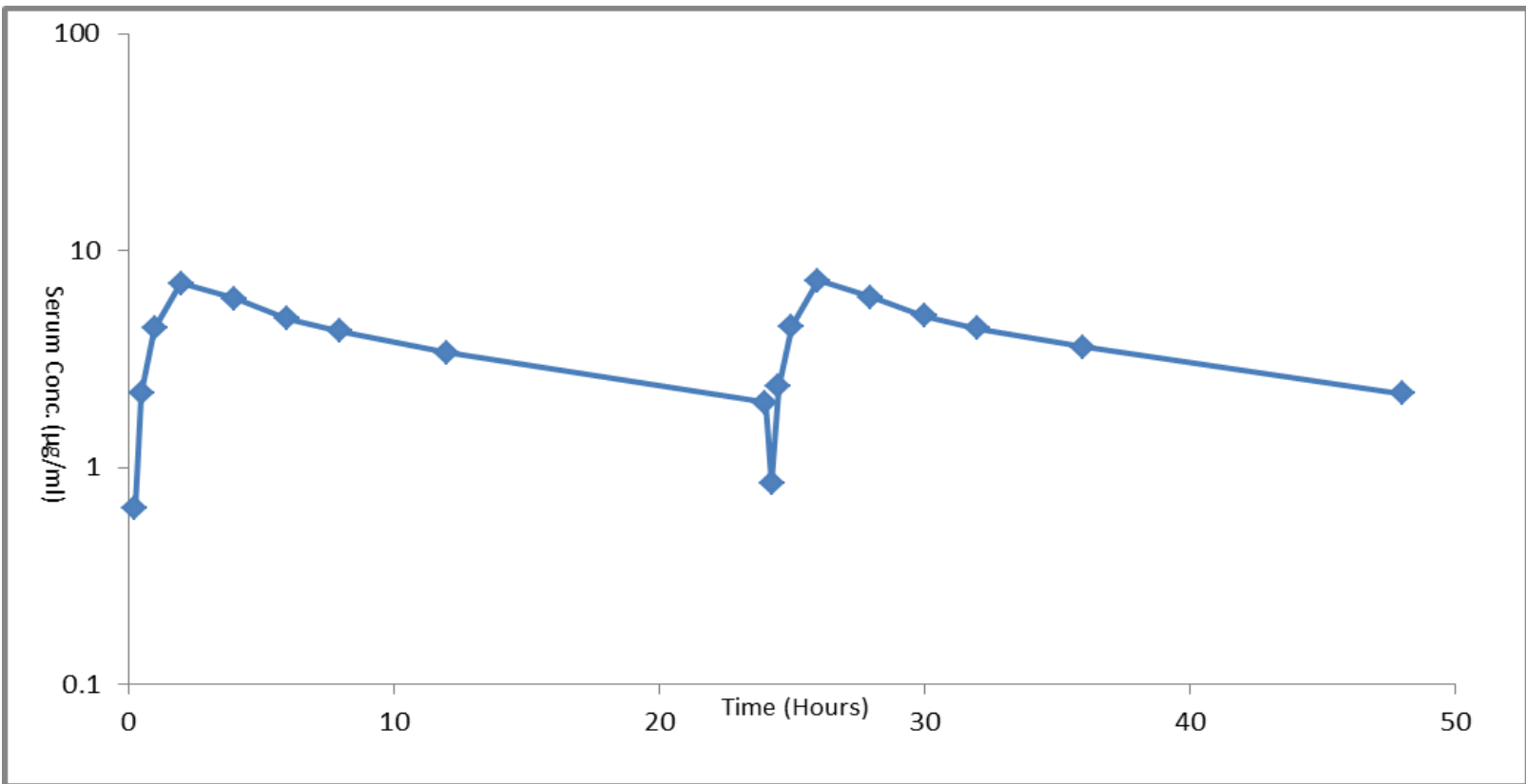

Fig. 1: Semi-Logarithmic Graph Depicting the Time Concentration of Toltrazuril in Plasma of Chickens Following Repeated Oral Administration of $7 \mathrm{Mg} / \mathrm{Kg}$ B.Wt. $(\mathrm{N}=10)$.

Table 1: Pharmacokinetics of Toltrazuril in Chickens after Repeated Oral Administration of $7 \mathrm{Mg} / \mathrm{Kg} . \mathrm{B} . \mathrm{Wt}$. (N=10), Mean \pm S.E.

\begin{tabular}{llll}
\hline Parameter & Unit & First dose & Second dose \\
\hline $\mathrm{K}_{\mathrm{el}}$ & $\mathrm{h}-1$ & $0.046 \pm 0.008$ & $0.042 \pm 0.007$ \\
$\mathrm{t}_{1 / 2 \beta}$ & $\mathrm{h}$ & $14.92 \pm 1.28$ & $16.19 \pm 1.60$ \\
$\mathrm{C}_{\max \text { (Calculated) }}$ & $\mu \mathrm{g} / \mathrm{ml}$ & $6.56 \pm 1.26$ & $6.70 \pm 0.60$ \\
$\mathrm{~T}_{\max (\text { Calculated) }}$ & $\mathrm{h}$ & $2.56 \pm 0.16$ & $2.59 \pm 0.35$ \\
$\mathrm{AUC}_{0-24}$ & $\mu \mathrm{g} . \mathrm{h} / \mathrm{ml}$ & $88.58 \pm 1.60$ & $92.82 \pm 1.45$ \\
$\mathrm{AUC}_{0-\infty}$ & $\mu \mathrm{g} . \mathrm{h} / \mathrm{ml}$ & $131.65 \pm 4.45$ & $144.23 \pm 6.34$ \\
$\mathrm{MRT}_{0-24}$ & $\mathrm{~h}$ & $9.56 \pm 1.22$ & $9.72 \pm 0.98$ \\
$\mathrm{MRT}_{0-\infty}$ & $\mathrm{h}$ & $21.33 \pm 1.90$ & $23.14 \pm 1.66$ \\
\hline
\end{tabular}

$\mathrm{C}_{\max }=$ maximal concentration; $\mathrm{T}_{\max }=$ when the maximal serum concentration is reached; $\mathrm{AUC}_{0-\mathrm{t}}=$ area under serum concentration-time curve; $\mathrm{t}_{1 / 2 \beta}=$ Elimination half-life; $\mathrm{MRT}=$ mean residence time; $\mathrm{K}_{\mathrm{el}}=$ first-order elimination rate constant.

Table 2: Tissue Concentration of Toltrazuril $(\mu \mathrm{g} / \mathrm{g})$ in Different Tissues after Repeated Oral Administration of $7 \mathrm{Mg} / \mathrm{Kg} . \mathrm{B} . \mathrm{Wt}$. (N=45), Mean \pm S.E.

\begin{tabular}{|c|c|c|c|c|c|c|c|}
\hline & Lung & Heart & Liver & Kidney & $\begin{array}{l}\text { Thigh } \\
\text { muscle }\end{array}$ & $\begin{array}{l}\text { Breast } \\
\text { muscle }\end{array}$ & $\begin{array}{l}\text { Fat and } \\
\text { skin }\end{array}$ \\
\hline $\begin{array}{l}\text { Days after the } 2 \text { nd } \\
\text { dose }\end{array}$ & \multicolumn{7}{|c|}{ Toltrazuril concentrations ( $\mu \mathrm{g} / \mathrm{g})$} \\
\hline 1 & $4.50 \pm 0.02$ & $4.40 \pm 0.09$ & $4.70 \pm 0.03$ & $5.89 \pm 0.07$ & $3.45 \pm 0.02$ & $2.60 \pm 0.07$ & $1.90 \pm 0.02$ \\
\hline 2 & $3.20 \pm 0.03$ & $3.11 \pm 0.01$ & $3.95 \pm 0.01$ & $3.13 \pm 0.06$ & $1.11 \pm 0.09$ & $1.22 \pm 0.01$ & $1.10 \pm 0.07$ \\
\hline 3 & $2.88 \pm 0.03$ & $2.84 \pm 0.09$ & $2.15 \pm 0.03$ & $2.22 \pm 0.02$ & $0.64 \pm 0.01$ & $0.61 \pm 0.07$ & $0.77 \pm 0.06$ \\
\hline
\end{tabular}




\begin{tabular}{llllllll}
\hline 4 & $1.20 \pm 0.02$ & $1.25 \pm 0.06$ & $1.25 \pm 0.02$ & $1.47 \pm 0.06$ & $0.31 \pm 0.07$ & $0.14 \pm 0.03$ & $0.22 \pm 0.07$ \\
5 & $0.60 \pm 0.04$ & $0.50 \pm 0.04$ & $0.79 \pm 0.06$ & $0.88 \pm 0.02$ & N.D & N.D & N.D \\
6 & $0.47 \pm 0.06$ & $0.25 \pm 0.08$ & $0.40 \pm 0.08$ & $0.47 \pm 0.05$ & N.D & N.D & N.D \\
7 & $0.20 \pm 0.05$ & N.D & $0.22 \pm 0.05$ & $0.25 \pm 0.06$ & N.D & N.D & N.D \\
8 & N.D & N.D & N.D & N.D & N.D & N.D & N.D \\
9 & N.D & N.D & N.D & N.D & N.D & N.D & N.D \\
10 & N.D & N.D & N.D & N.D & N.D & N.D & N.D \\
11 & N.D & N.D & N.D & N.D & N.D & N.D & N.D \\
12 & N.D & N.D & N.D & N.D & N.D & N.D & N.D \\
13 & N.D & N.D & N.D & N.D & N.D & N.D & N.D \\
14 & N.D & N.D & N.D & N.D & N.D & N.D & N.D \\
15 & N.D & N.D & N.D & N.D & N.D & N.D & N.D \\
\hline
\end{tabular}

N.D = Not detected.

24 hours following the second dose, three chickens were slaughtered on daily bases for 15 days.

\section{Discussion}

The prudent use of toltrazuril in veterinary medicine, especially in poultry production is strongly required to preserve the safety and efficacy of toltrazuril in the future. Therefore, its kinetics characteristic should be considered to select the dosage regimens which induce the maximum efficacy and minimize the development of resistance.

In the present study, the mean $\mathrm{C}_{\max }$ of toltrazuril calculated after repeated oral administrations were 6.56 and $6.70 \mu \mathrm{g} / \mathrm{ml}$ attained at 2.56 and $2.59 \mathrm{~h}$ after the first and second dose, respectively. However, different results were obtained in broiler chickens at dose of $10 \mathrm{mg} / \mathrm{kg}(16.4 \mu \mathrm{g} / \mathrm{ml}$ attained at $5.0 \mathrm{~h})$ and at dose of $20 \mathrm{mg} / \mathrm{kg}(25.2 \mu \mathrm{g} / \mathrm{ml}$ attained at 4.7 h) [12], in rabbits at dose of $10 \mathrm{mg} / \mathrm{kg}(30.2 \mu \mathrm{g} / \mathrm{ml}$ attained at $20.0 \mathrm{~h})$ [10], in rats $(25.0 \mu \mathrm{g} / \mathrm{ml}, 20 \mathrm{mg} / \mathrm{kg}$, [13] and in calves at dose of $15 \mathrm{mg} / \mathrm{kg}(33.41 \mu \mathrm{g} / \mathrm{ml})$ [13] Similar findings were obtained in piglets at dose of $20 \mathrm{mg} / \mathrm{kg}(7.5 \mu \mathrm{g} / \mathrm{ml})$ [14], in horses at dose of $10 \mathrm{mg} / \mathrm{kg}(4.5 \mu \mathrm{g} / \mathrm{ml})$ [15]. The apparent elimination half-life of toltrazuril was 14.92 and $16.14 \mathrm{~h}$ after the first and second dose, respectively. This finding was different to the elimination half-life of $55 \mathrm{~h}$ after oral dosing at $10 \mathrm{mg} / \mathrm{kg}$ to horses [15]. However, terminal elimination half-life of broilers was observed $11.4 \mathrm{~h} \mathrm{[16].} \mathrm{In}$ European Medicines Agency (EMEA) reports, the elimination half-lives of rats, pigs and calves were observed 23.0, 148.2 and 154.0 hours following oral administration of ${ }^{14} \mathrm{C}$-toltrazuril at a dose of $20 \mathrm{mg} / \mathrm{kg}$ in rats and pigs, and 15 $\mathrm{mg} / \mathrm{kg}$ in calves [13], [14]. These clearly indicate species-specific differences in terms of absorption and elimination characteristics of toltrazuril following oral administration. The gastro-intestinal absorption of toltrazuril depends on lipophilic characteristics and dissociation rate and it is expected to be well absorbed following oral administration [17]. The physiological $\mathrm{pH}$ in the avian stomach is low, particularly at the gizzard which is considered as a powerful triturating machine and facilitates the disintegration of solid oral dosage forms [18]. These properties could contribute to enhance toltrazuril solubility and its absorption processes in broilers compared to the other species.

Tissue residue $(\mu \mathrm{g} / \mathrm{g})$ of toltrazuril following repeated oral administration revealed wide distribution of the drug in the tested tissues (brain, lung, heart, liver, muscle, skin and fat). The tissue concentrations of toltrazuril were highest in the kidney and decreased in the following order: liver > lung > heart > muscle > skin and fat. No toltrazuril residues were detected in tissues and plasma after eight days following repeated oral administration. Similar findings were found in chicken and porcine tissues [19] and skin and fat of chicken and pig [20].

\section{Conclusion}

Toltrazuril was absorbed very well through gastro-intestinal tract and slowly eliminated after repeated oral administration at a dose of $7 \mathrm{mg} / \mathrm{kg}$ in broiler chickens. Toltrazuril residue levels reached a maximum 7 days after the second dose in all tissue samples.

\section{Conflict of Interests Statement}

The authors declare that there is no conflict of interests regarding the publication of this paper.

\section{References}

[1] P. Allen, H. Danforth, P. Augustine, Dietary modulation of avian coccidiosis, International Journal of Parasitology (28) (1998) 1131-1140. http://dx.doi.org/10.1016/S0020-7519(98)00029-0.

[2] P. Augustine, Cell sporozoite interactions and invasion by apicomplexan parasites of the genus Emieria, International Journal of Parasitology (31) (2001) 1-8. http://dx.doi.org/10.1016/S0020-7519(00)00150-8.

[3] H. Chapman, Chemotherapy of caecal coccidiosis: efficiacy of toltrazuril, sulphaquinoxaline/pyrimethamine and amprolium/ethopabate, given in drinking water, against field isolates of Eimeria tenella, Research in Veterinary Science (46) (1989) 419-420. 
[4] C. Chauve, Caracterisation de la faune coccidienne des Anatinae decomestique (Anax platyrhynchos, Cairina moschata et leur hybride le cannrd mulard). Description d'une novella espece Eimeria mulardi. Cycle evolutif et pathogenenicite. These Dect. D'Universite Lyon, 1994; $116 \mathrm{pp}$.

[5] C. Chauve, J. Gastellu, M. Reybaud, Patyhogenicite d,Eimeria mulardi chez le canard mulard après infection experimentale. Precision des stades pathogens. Avian Pathology (23) (1994) 557-568. http://dx.doi.org/10.1080/03079459408419025.

[6] E. Benoit, T. Buronfosse, P. Delatour, Effect of cytochrome P-450 IA induction on enantioselective metabolism and pharmacokinetics of an aryltrifluoromethyl sulfide in the rat, Chirality (6) (1994) 372-377. http://dx.doi.org/10.1002/chir.530060503.

[7] T.Sreter, Z. Szell, I. Varega, Attempted chemorophylaxis of cryptosporidiosis in chickens using diclazuril, toltrazuril or garlic extract, Journal of Parasitology (85) (1999) 989-991. http://dx.doi.org/10.2307/3285847.

[8] H. Mehlhorn, G. Ortmann-Falkenstein, A. Haberkon, The effects of sym. Triazinones on developmental stages of Emeria tenella, E. maxima and E. acervulina: a light and electron microscobical study, Z. Parasitenkd (70) (1984) 173-182. http://dx.doi.org/10.1007/BF00942219.

[9] M. Reynaud, C. Chauve, J. Gastellu, J. Gounel, Administration of toltrazuril during experimental coccidiosis in mule ducks: comparison of the efficacy of a single administration at two different endogenous stages, Veterinary Parasitology (81) (1999) 265-274. http://dx.doi.org/10.1016/S0304-4017(98)00256-8.

[10] M. Kim, J. Lim, Y. Hwang, B. Park, I. Song, H. Yun, Plasma disposition of toltrazuril and its metabolites, toltrazuril sulfoxide and toltrazuril sulfone in rabbits after oral administration, Veterinary Parasitology (169) (2010) 51-56. http://dx.doi.org/10.1016/j.vetpar.2009.12.011.

[11] European Agency for the evaluation of European Medicines Agency (EMEA). Committee for Veterinary Medicinal Products (Toltrazuril, Summary Report 3). The Euroean Agency for the evaluation of Med. Products. EMEA/MRL/620 699. UK, 2001.

[12] M. Kim, B. Park, Y. Hwang, et al, Pharmacokinetics and metabolism of toltrazuril and its major metabolites after oral administration in broilers. Journal of Poultry Science (50) (2013) 257-261. http://dx.doi.org/10.2141/jpsa.0120050.

[13] European Agency for the evaluation of European Medicines Agency (EMEA). Committee for Veterinary Products/The European Agency for the Evaluation of Medicinal Products. Toltrazuril (Extension to Pig)—Summary Report, EMEA/MRL/907/00-FINAL, 2000.

[14] European Agency for the Evaluation of European Medicines Agency (EMEA). Committee for Veterinary Products/The European Agency for the Evaluation of Medicinal Products. Toltrazuril (Extension to Pigs) - Summary Report, EMEA/MRL/620/99-FINAL, 1999.

[15] T. Tobin, L. Dirikolu, J. Harkins, et al, Preliminary pharmacokinetics of diclazuril and toltrazuril in the horse, American Association of Equine Practitioners (43) (1997) 15-16.

[16] J. Lim, B. Park, M. Kim, Y. Hwang, I. Song, H. Yun, Pharmacokinetics of toltrazuril after oral administrations in broilers, Journal of Veterinary Clinics (24) (2007) 308-311.

[17] L. Dirikolu, W. Karpiesiuk, A. Lehner, C. Hughes, D. Granstrom, T. Tobin, Synthesis and detection of toltrazuril sulfone and its pharmacokinetics in horses following administration in dimethylsulfoxide, Journal of Veterinary Pharmacology and Therapeutics (32) (2009) 368-378. http://dx.doi.org/10.1111/j.1365-2885.2008.01053.x.

[18] B. Vermeulen, P. De Backer, J. Remon, Drug administration to poultry, Advanced Drug Delivery Reviews (54) (2002) $795-803$. http://dx.doi.org/10.1016/S0169-409X(02)00069-8.

[19] J. Zhaoling, Z. Lifang, Z. Chong, Z. Xiao, X. Feiqun, SPE-UPLC-UV Method for the Determination of Toltrazuril and its Two Metabolite Residues in Chicken and Porcine Tissues, Chromatographia (77) (2014) 1705-1712. http://dx.doi.org/10.1007/s10337-014-2759-9.

[20] Z. Wenli, J. Zhaoling, Z. Lifang, et al, Simultaneous determination of toltrazuril and its metabolites in chicken and pig skin and fat by UPLCUV method, Journal of Chromatography B (972) (2014) 89-94. 